ISSN 0103-5150

Fisioter. Mov., Curitiba, v. 29, n. 1, p. 45-52, Jan./Mar. 2016

Licenciado sob uma Licença Creative Commons

DOI: http://dx.doi.org.10.1590/0103-5150.029.001.A004

(c)

\title{
Manual therapy and segmental stabilization in the treatment of cervical radiculopathy
}

\author{
A terapia manual e a estabilização segmentar \\ no tratamento da radiculopatia cervical
}

\author{
Rafael Souza Aquaroli ${ }^{[a]}$, Elder Soares Camacho ${ }^{[a]}$, Luis Marchi ${ }^{[b]}$, Luiz Pimenta ${ }^{[b] *}$ \\ [a] Irmandade Santa Casa da Misericórdia de São Paulo, São Paulo, SP, Brazil \\ [b] Universidade Federal de São Paulo, (UNIFESP), São Paulo, SP, Brazil
}

\begin{abstract}
Introduction: Cervical radiculopathy (CR) is one of the diseases that most affect the cervical spine, causing radicular symptoms in the ipsilateral limb. Conservative treatment aim recover of both mechanical and physiological functions through neural mobilization techniques, along with the activation of the deep neck flexors with cervical segmental stabilization, combining techniques of joint mobilization and manipulation, which seeks mobility improvement of crucial areas of the cervical spine. The objective of this study was to evaluate a multimodal treatment to enhance the outcomes of conservative care in patients diagnosed with CR. Methods. The sample consisted of 11 patients with CR, between 21 and 59 years old, 3 female and 8 male. It was recorded the Visual Analogue Scale (VAS) for pain, the Functional Development of the Neck Pain and Disability Scale (NPDS) and the goniometry during shoulder abduction. The intervention plan was composed by neural mobilization, intermittent cervical traction, pompages, stretching, myofascial inhibition techniques, manipulative techniques and cervical segmental stabilization exercises. After 12 weeks of treatment, subjects underwent a new evaluation process. Results: Before the treatment, subjects reported an average pain of $7( \pm 1.48)$ in VAS,
\end{abstract}

\footnotetext{
* RSA: Specialist, e-mail: r.aquaroli@equilibriofitefisio.com.br

ESC: Specialist, e-mail: eldercamacho@gmail.com

LM: MSc, e-mail: marchi@patologiadacoluna.com.br

LP: MD PhD, e-mail: luizpimenta@luizpimenta.com.br
}

Fisioter Mov. 2016 Jan/Mar;29(1):45-52 
whose dropped to average $1.18( \pm 1.99)(\mathrm{p}<0.01)$. Functional disability evaluated in NPDS was $36( \pm 10.95)$ before treatment decreasing to $11.45( \pm 9.8)(\mathrm{p}<0.01)$ after the treatment. Range of motion of the ipsilateral upper limb was restores by increasing from $9.2^{\circ}( \pm 8.2)$ to $137^{\circ}( \pm 24.4)(\mathrm{p}<0.01)$. Conclusion: The proposed treatment approach was effective, significantly improving the results of analgesia and functional disability a series of cases of patients diagnosed with cervical radiculopathy.

Keywords: Musculoskeletal manipulations. Neck pain. Radiculopathy. Physical therapy. Specialty.

\section{Resumo}

Introdução: Sabe-se que a radiculopatia cervical $(R C)$ é uma das patologias que mais acometem a coluna cervical, gerando sintomas radiculares na extremidade superior ipsilateral. Desta forma, no tratamento conservador, busca-se recuperar a função mecânica e fisiológica do sistema nervoso por intermédio da técnica de mobilização neural, além da ativação dos músculos flexores profundos do pescoço com a estabilização segmentar cervical, aliando técnicas de manipulação e mobilização articular, que têm como objetivo melhorar a mobilidade das áreas importantes na mecânica cervical. O objetivo foi avaliar um tratamento multimodal para potencializar o resultado do tratamento conservador nos pacientes diagnosticados com RC. Materiais e métodos: A amostra foi composta por 11 pacientes com diagnóstico médico de RC, com idade entre de 21 e 59 anos, sendo 3 mulheres e 8 homens. Os indivíduos foram avaliados e classificaram sua dor cervical na EVA (Escala Visual Analógica), além de responder ao questionário funcional Development of the Neck Pain and Disability Scale (NPDS) e à goniometria de abdução do ombro ipsilateral a compressão radicular. $O$ método de intervenção utilizado foi composto por: mobilização neural, tração cervical intermitente, pompages, stretching, técnicas de inibição miofascial, técnicas manipulativas de correção e exercícios de estabilização segmentar cervical. Após 12 semanas de tratamento, os indivíduos foram submetidos a um novo processo de avaliação. Resultados: Antes do processo de intervenção, os indivíduos relataram média de dor $7( \pm 1,48)$ na EVA, cuja média reduziu-se a 1,18 $( \pm 1,99)(p<0,01)$. Referente à incapacidade funcional avaliada no NPDS, a pontuação média pré-tratamento atingiu média de $36( \pm 10,95)$, diminuindo para $11,45( \pm 9,8)(p<0,01)$ após o tratamento proposto, que também se mostrou efetivo na recuperação da amplitude de movimento do membro superior ipsilateral, aumentando a média de $9,2^{\circ}( \pm 8,2)$ para $137^{\circ}( \pm 24,4)(p<0,01)$. Conclusão: 0 método de tratamento proposto mostrou-se eficaz, melhorando significativamente os resultados de analgesia e incapaciade funcional de uma série de casos de individuos diagnósticados com radiculopatia cervical.

Palavras-chave: Fisioterapia. Sistema Único de Saúde. Formação de recursos humanos.

\section{Introduction}

Cervical radiculopathy (CR) is one of the diseases that most affect the cervical spine, herniated disc and osteophytes are two of the injures that can cause CR. (1) Cervical herniated disc compresses the nerve root causing inflammation and radicular symptoms in the ipsilateral limb. $(2,3)$ Symptoms tend to follow the corresponding root dermatome. (4) The reported prevalence of CR is 3, 3 cases per 1000 people with peak incidence in the fourth and fifth decade of life $(2,1$ cases per 1000 people). (5) In the diagnostics of $\mathrm{CR}$, the gold standards are Magnetic Resonance Imaging (MRI) and electromyography exams (6).
Due to the consequences that neural dysfunctions, caused by CR, can generate the patients, seeks to recover mechanical and nerve physiological function, restoring the length and the mobility, and the secondary dysfunctions in the musculoskeletal structures that receive their innervation. This aims are tangible with neural mobilization techniques, which are composed of passive movements applied to neural tissue $(7,8)$.

In addition to neural mobilization, several techniques and methods have been used to treat patient with CR. Some aim to activate and strengthen the deep neck flexor muscles, in this case, muscles that act in spine stabilization. Other manipulation techniques are used to improve mobility in important players in the cervical spine biomechanics. 
Few studies have already conducted a multimodal treatment as strategy, relating these different approaches previously mentioned to enhance therapeutic outcomes in individuals with CR $(4,9)$.

Due to the complexity of treatment of patients with CR, to the different methods and techniques used for treatment, and to the discordant results in the literature, this study evaluated the effects of multimodal treatment associating manual therapy techniques and cervical segmental stabilization in patients diagnosed with CR.

\section{Materials e methods}

This study is a series of cases from a single center. The sample consisted of 11 patients with CR, between 21 and 59 years old and average of 41.8 years, standard deviation (SD 2,8), 3 female and 8 male who were selected from the pre-established criteria. Inclusion criteria: medical diagnosis of CR, age between 18 and 65 years and Visual Analogue Scale (VAS) score greater than 3. Exclusion criteria: previous surgery in cervical or thoracic spine, physiotherapy treatment in the last three months and neuromuscular and/or rheumatic diseases.

Patients selected by inclusion criteria initiated the evaluation process with a physiotherapist who took note the clinical history, complaints and characteristics of the symptoms. They have also answered a functional questionnaire "Functional Development of the Neck Pain and Disability Scale" (NPDS) (10). This questionnaire evaluates and quantifies the pain and disability during functional activities of patients suffering from neck pain.

Starting the physical examination, the goniometry in shoulder abduction ipsilateral was performed, in which the patients standing performed the shoulder abduction until the onset of symptoms, when the angle value was measured.

To check if there was a nerve root compression or sensitization, it was performed the active test for shoulder abduction, in which the patient is erect position and perform shoulder abduction with cervical neutral position and then repeating in lateral-flexion ipsilateral and contralateral. In supine position the following tests were performed: upper limb tension test (ULTT) 1 the median nerve, ULTT 2 to the radial nerve and ULTT 3 to ulnar nerve. Positive tests were recorded and the corresponding nerves were later covered with neural mobilization technique (11). It was also performed the Klein test, which assesses if there is vertebral artery compression. If test is positive, the cervical manipulation is not indicated (12).

Additionally, global mobility test was conducted to assess hypermobility and hypermobility areas, and results were taken into account to execute mobilization techniques and articular manipulation. In patients in a prone position was performed the palpation of all spinous process of spine. The sensitized metameres underwent to the Mitchel's test to investigate the correspondent osteopathic lesion (13).

Once done the case investigation, the process of intervention with neural root mobilization technique began with lateral deviation in the level affected with frequency of three series of 60 mobilizations, with interpolated cervical traction oscillatory technique for 30 repetitions, and the cervical traction sustained for 1 minute. With the progression of the technique and improvement of symptoms, increased up the shoulder abduction with the nerve voltage parameters affected. After reaching 60 degrees of abduction, the distal neural mobilization technique was used for loss of complacency, this also often three sets of 60 repetitions (11).

Intermittent cervical traction and global pompage were techniques used during treatment, as well stretching techniques and myofascial inhibition with trigger points of the upper trapezius, scapula lift, sternocleidomastoid, pectoralis minor, rhomboid, scalene, subscapularis, supraspinatus, infraspinatus and suboccipital. Techniques were used for muscle with spasm and the players that act as joint blockade found in the cervical, scapula, first rib and thoracic spine $(13,14,15,16)$. Upon existing osteopathic lesion was performed the correction manipulative technique Extension/ Rotation/ Inclination (ERI), Flexion/Rotation/Inclination (FRI), Bilateral Extension and Lateral Flexion always starting by correcting the Occipito hinges, Atlas, Axis or cervicothoracic, and then correcting the others segments, cervical or thoracic $(13,15)$.

After the fourth session, segmental stabilization exercises took place. The first exercise was the activation of the deep neck flexor muscles on the ball with the flexion of upper cervical spine or cervical rectification. All others exercises were performed with the activation deep neck flexor muscle keeping the upper cervical spine $(4,9,17,18)$. After 12 weeks of treatment, the patients were submitted to another evaluation, identical to the one held before and those results were tabulated and compared to baseline. 


\section{Results}

The sample consisted of 11 patients; all fit in inclusion criteria and performed 12 weeks of treatment without drop-offs. Ten out of eleven patients (91\%) had compressive stenosis in C5 - C6 level, five patients (46\%) had stenosis in C6 - C7 level and only two patients (19\%) had radicular stenosis in C4 - C5, and six patients presented more than one affected level. The most affected nerve was the radial nerve (91\%), followed by median $(63 \%)$ and ulnar nerve $(9 \%)$.

After 12 weeks of treatment, ten out of eleven patients $(91 \%)$ had significant improvement in pain measured by VAS. Only patient \# 5 didn't reach significant improvement, maintaining the same symptoms reported in the baseline (Figure 2). This patient was forwarded again to the medical service and weeks later was submitted to anterior cervical discectomy and fusion (ACDF) due to central stenosis on C5 - C6 level. No patient had aggravation during treatment.

At baseline, before treatment, the study group reported an average score of 7 pain in VAS pain questionnaire and after treatment for 12 weeks, the average value diminished to 1,2 (Figure 2). This result was statistically significant $(\mathrm{p}<0.001)$.

It was recorded the goniometry result for shoulder abduction ipsilateral to symptoms. The average value at baseline was $9.2^{\circ}$ and after treatment was $137^{\circ}$ (Figure $3)$. The difference is statistically significant $(\mathrm{p}<0.001)$. Only patient \#5 had no significant gain in this test.

Figure 4 shows the improvement of functional outcomes by NPDS. There was a reduction of approximately about $65 \%$ in this outcome from the beginning to end of treatment, from an average 36 to 12 points in the scale. The difference is statistically significant $(\mathrm{p}<0.001)$.

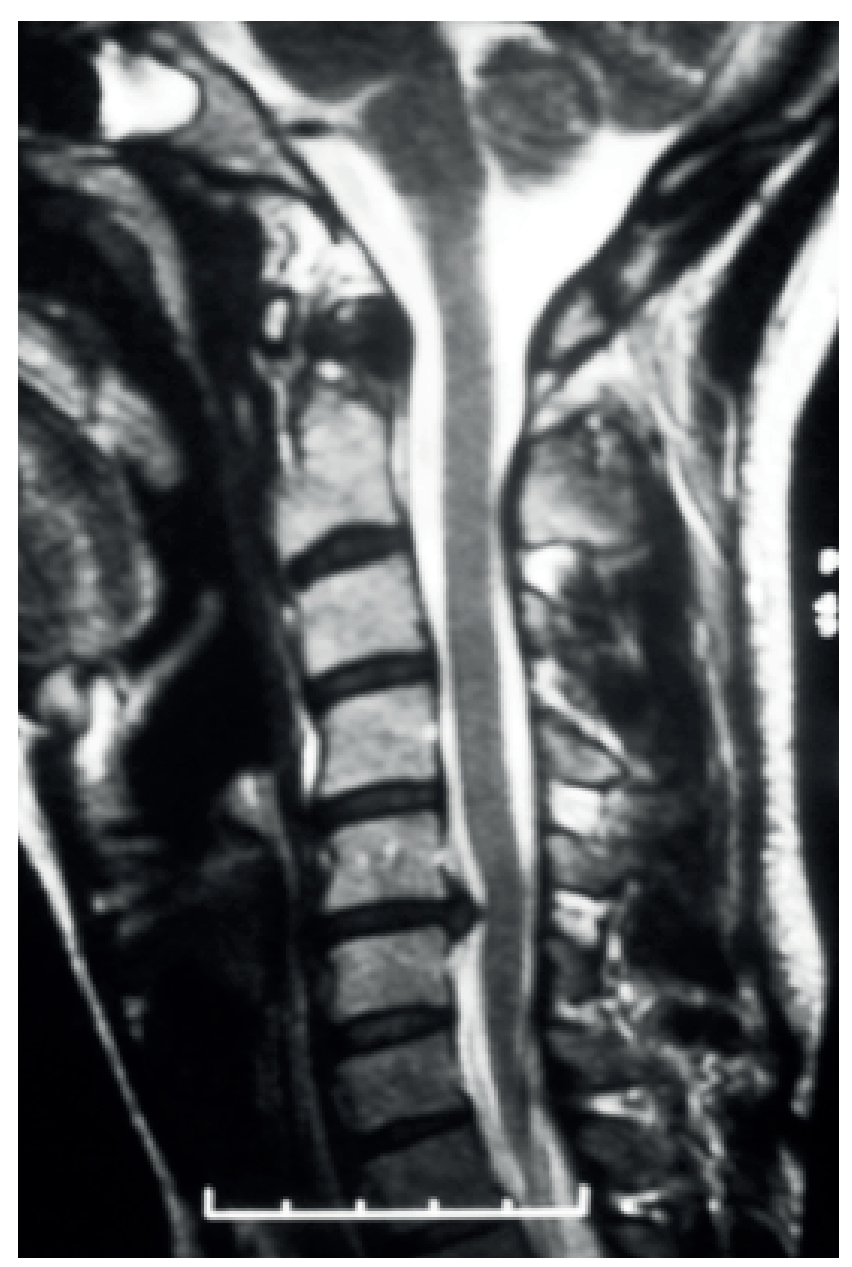

Figure 1 - Case example. Diagnosis of C5-C6 disc herniation in a sagittal T2-MRI image. Patient reported cervical radiculopathy . 

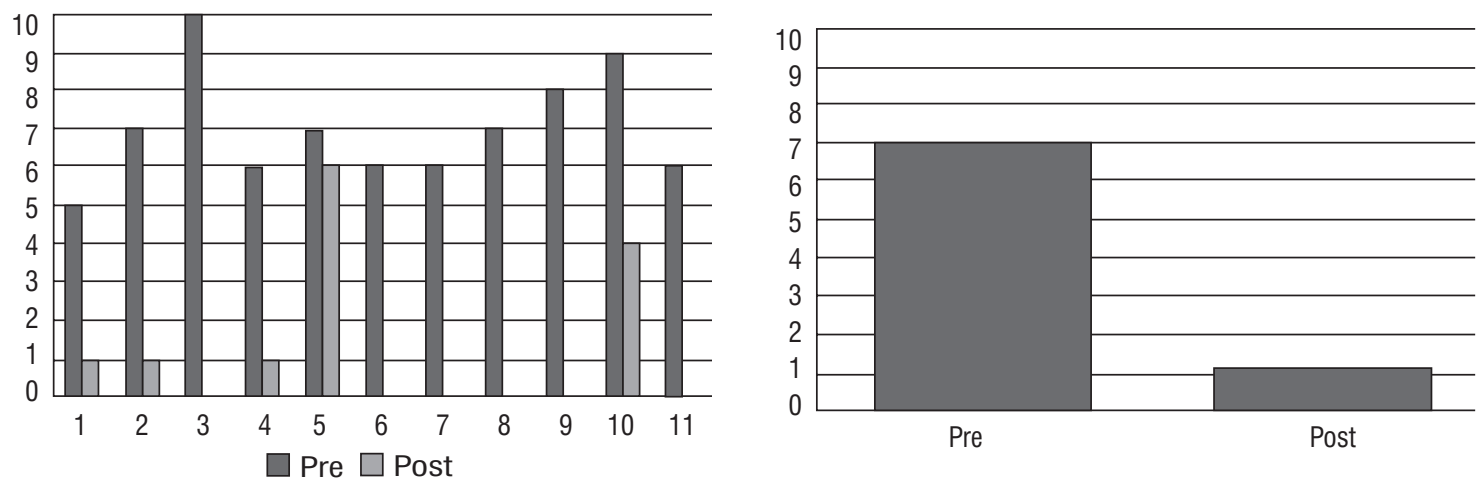

Figure 2 - Visual Analogue Scale (VAS) for pain. (A) Individual results of patients before treatment (VAS_pre) and after 12 weeks of treatment (VAS_ post). (B) Average values evidence a statistically significant reduction $(p<0.001)$ at the final assessement

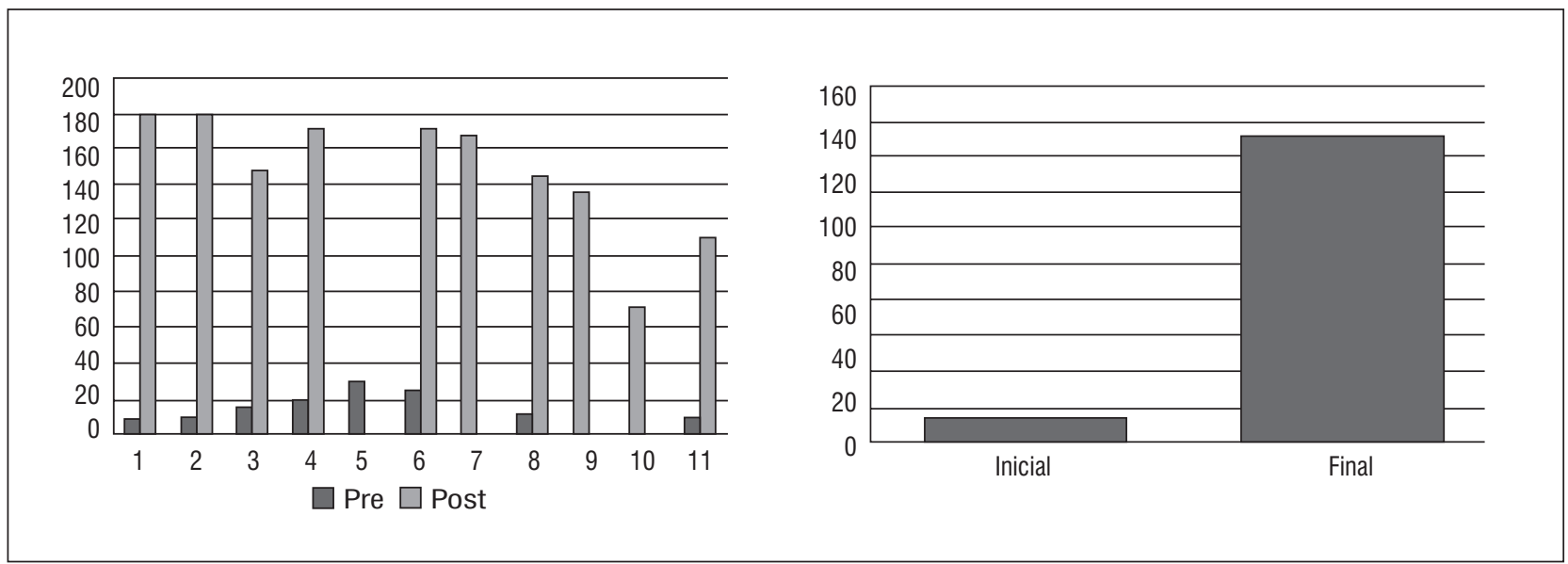

Figure 3 - Evolution of shoulder abduction of motion after surgery. (A) Individual results goniometry before treatment (initial Gonio) and 12 weeks of treatment (final Gonio). (B) Average results of the study group, showing statistically significant increase $(p<0.001)$ range of motion after treatment. Values are shown in degress $\left(^{\circ}\right)$

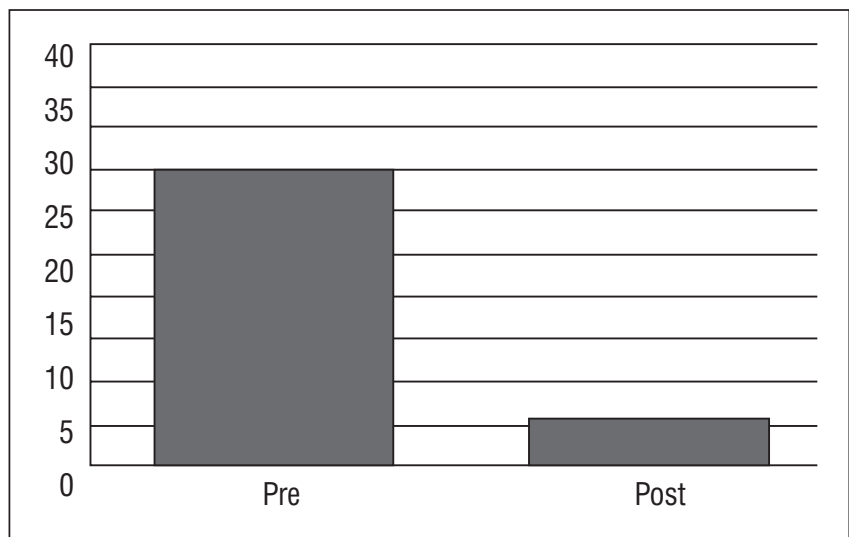

Figure 4 - Comparison of the initial with the final score of the NPDS questionnaire, showing decrease of the physical disability $(p<0.001)$.

\section{Discussion}

This study evaluated a multimodal treatment schedule for the treatment of cervical radiculopathy. The techniques used were of neural mobilization, intermittent cervical traction, pompages, stretching, myofascial inhibition techniques, manipulative technique of correction and cervical segment stabilization exercises.

Although cannot suggest cause and effect from case series, our results indicated that after 12 weeks the group submitted the multimodal treatment showed a significant decrease of pain. One patient didn't improved and was directed to a surgical procedure. Furthermore, the same treated 
group improved functional, i.e. significant decrease of functional disability. This shows that the treatment methods used can benefit most patients with cervical radiculopathy.

Yoshinari e Bonfá (19) showed that most cases of cervical radicular compression occur in the $\mathrm{C} 5, \mathrm{C} 6$ and C7 levels, therefore justifies the greater involvement of radial and median nerves, data that corroborates with this study.

Moeti and Marchetti (20) reported complete resolution of patients' pain in eight of 15 cases (53\%) with cervical radiculopathy treated with intermittent cervical traction, cervical segmental stabilization with high neck flexion, strengthening exercises of the cervical/scapular muscles, techniques of mobilization and manipulation. Cleland et al. (9) conducted a multimodal treatment in 11 patients with CR; they used techniques such as manual cervical traction, thoracic manipulation and strengthening of the deep neck flexor and scapular muscles. At the end of treatment, 10 of 11 patients (91\%) had improvement in pain and in questionnaire functional (NPNQ) during the six months follow-up. Similarly, Mark and Waldrop (4) showed that $75 \%$ of the subjects responded well to treatment with a reduction in pain (VAS) and functional improvement (NPDS) through the use of strengthening the deep neck musculature, intermittent cervical traction and thoracic spine manipulation.

Table 1 - Demographic and clinical data of patients included in the study

\begin{tabular}{ccccc}
\hline $\begin{array}{c}\text { Patient } \\
\#\end{array}$ & Gender & Age & $\begin{array}{c}\text { Afected } \\
\text { level }\end{array}$ & $\begin{array}{c}\text { Afected } \\
\text { nerve }\end{array}$ \\
\hline 1 & $\mathrm{~F}$ & 27 & $\mathrm{C} 5-\mathrm{C} 6$ & Radia//Median \\
2 & $\mathrm{~F}$ & 52 & $\mathrm{C} 5-\mathrm{C} 6 / \mathrm{C} 6-\mathrm{C} 7$ & Radial/Median \\
3 & $\mathrm{M}$ & 32 & $\mathrm{C} 4-\mathrm{C} 5 / \mathrm{C} 5-\mathrm{C} 6$ & Radial \\
4 & $\mathrm{M}$ & 21 & $\mathrm{C} 6-\mathrm{C} 7$ & Median \\
5 & $\mathrm{M}$ & 52 & $\mathrm{C} 5-\mathrm{C} 6$ & Radial \\
6 & $\mathrm{M}$ & 56 & $\mathrm{C} 5-\mathrm{C} 6 / \mathrm{C} 6-\mathrm{C} 7$ & Radial/Median \\
7 & $\mathrm{M}$ & 32 & $\mathrm{C} 5-\mathrm{C} 6 / \mathrm{C} 6-\mathrm{C} 7$ & Radial \\
8 & $\mathrm{M}$ & 45 & $\mathrm{C} 5-\mathrm{C} 6$ & Radial/Median \\
9 & $\mathrm{M}$ & 59 & $\mathrm{C} 5-\mathrm{C} 6 / \mathrm{C} 6-\mathrm{C} 7$ & Radial/Median \\
10 & $\mathrm{~F}$ & 35 & $\mathrm{C} 4-\mathrm{C} 5 / \mathrm{C} 5-\mathrm{C} 6$ & Radial \\
\hline 11 & $\mathrm{M}$ & 49 & $\mathrm{C} 5-\mathrm{C} 6$ & \\
\hline
\end{tabular}

Norlander et al. (21) theorized that the disturbances of the upper levels of the thoracic spine can cause biomechanical changes in cervical spine and indicated that the loss of upper thoracic mobility significantly increased the risk of cervical and shoulder pain. The thoracic manipulation can be an effective technique for reduction pain in cervical, but still lack quality evidence $(21,22,23)$.

Intermittent cervical traction has been widely used as an efficient tool for intervention in the treatment of CR. $(4,6,24,25,26)$ Pereira (27) conducted a study with cervical manipulation and neural mobilization in patients with cervicobrachialgia and noted $50 \%$ improvement in pain assessed by VAS.
In this study, it was observed a significant increase in range of motion of symptomatic upper limb after application of multimodal treatment. Przywara e Rezende (28) noted the significant effect on the motion amplitude both the cervical spine and symptomatic upper limb after neural mobilization of the median and radial nerves. Marinzeck (7) justified the pain reduction, reporting that neural mobilization seeks to restore the movement and the elasticity to the nervous system, which promotes the return their normal functions. Therefore, the technique assumed that if there is a mechanical/ physiological commitment of the nervous system (movement, elasticity, conduction, axoplasmic flow) 
may result in other disorders in the nervous system itself or in musculoskeletal structures that receive innervation. According Butler, (11) through the neural mobilization is possible to ensure the proper functioning of nervous system, because this technique leads to maintain of axonal transport, which is dependent on uninterrupted blood flow.

Several studies observed inhibition and weakness of deep neck muscles in patients with cervical pain $(17,29,30)$. The inhibition of the deep neck muscles causes a mechanical disturbance in cervical spine and overloads the intervertebral discs, which eventually can cause a CR. So the main objective of strengthening the deep neck musculature, especially the deep neck flexors, is to restore the normal cervical mechanical and reduce the overloads the intervertebral discs (31).

Petersen (32) showed that patients instructed to strengthen the deep neck flexor and scapular muscles showed improvement of pain and disability.

According to Murphy, (33) the deep cervical flexor muscles are essentially the Longus Coli and Longus Capitus muscles. They play a key role in the cervical spine conditions. The orientation of their fibers suggests specifics roles, including lateral flexion and cervical spine flexion. Additionally, they appear to play the role of local stabilizer, allowing proper mechanics and promoting the cervical curve rectification or upper cervical flexion, which acts opening the facets and allows the action cervical muscles, scapula and thoracic spine without compromising facets and intervertebral discs.

\section{Conclusion}

The treatment method used in this study was efficient to decrease the pain and functional disability in a series of cases diagnosed with cervical radiculopathy. Although it cannot suggest cause and effect, this study provides the initial basis of the hypothesis that this multimodal treatment may have a scientific merit. Future clinical trials should be performed to evaluate comparatively the efficiency of other methods and the technique used in this study for the treatment of patients with cervical radiculopathy.

\section{References}

1. Dox I, Melloni BJ, Eisner GM. Melloni's IllustratedMedical Dictionary. Baltimore, MD: Williams \& Wilkins Co; 1979.

2. Jenis LG, An HS. Neck pain secondary to radiculopathy of the fourth cervical root: an analysis of 12 surgically treated patients. J Spinal Disord. 2000;(13):345-9.

3. Tanaka N, Fujimoto Y, An HS, Ikuta Y, Yasuda M. The anatomic relation among the nerve roots, intervertebral foramina, and intervertebral discs of the cervical spine. Spine. 2000;(25):286-91.

4. Waldrop MA. Diagnosis and Treatment of Cervical Radiculopathy Using a Clinical Prediction Rule and a Multimodal Intervention Approach: A Case Series. J Orthop Sports Phys Ther. 2006;(36):152-9.

5. Wainner RS, Gill H. Diagnosis and nonoperative management of cervical radiculopathy. J Orthop Sports PhysTher. 2000;(30):728-44.

6. Jahnke RW, Hart BL. Cervical stenosis, spondylosis, and herniated disc disease. Radiol Clin North Am.1991;(29):777-91.

7. Marinzeck S. Mobilização neural - aspectos gerias. São paulo, 2000. Available from: http://tinyurl.com/ j6rsnjr.

8. Santos V A influência da mobilização do sistema nervoso na câimbra do escrivão. Revista Terapia Manual. Abril 2004; 2(4):166-71.

9. Cleland JA, Whitman JM, Fritz JM, Palmer JA. Manual Physical Therapy, Cervical Traction and Strengthening Exercises in PatientsWith Cervical Radiculopathy: A Case Series. J Orthop Sports Phys Ther. 2005;(35):802-11.

10. Wheeler AH, Goolkasian P, Baird AC, Darden BV 2nd. Development of the Neck Pain and Disability Scale. Item analysis, face, and criterion-related validity. Spine. 1999 Jul 1;24(13):1290-4.

11. Butler D. Mobilização do Sistema Nervoso. Barueri, SP: Manole; 2003. 
12. Klein JD, Garfin SR. Clinical evaluation of patients with spinal disorders, sec.3. In: Garfin SR, Vaccaro AR. Spine - Orthopaedic Knowledge Update. 1st ed., American Academy of Orthopaedic Surgeons, Rosemont IL; 1997.

13. Ricard F.Tratamento Osteopático das Lombalgias e Ciáticas. Rio de Janeiro, RJ:Atlântica; 2001.

14. Simons DG, Travel JG. Dor e Disfunção Miofascial: Manual dos pontos Gatilhos- Membros Superiores. V.1. 2 ed. Porto Alegre,RS:Artmed; 2005.

15. Bienfait M. Bases Elementares Técnicas de Terapia Manual e Osteopatia. São Paulo, SP. Summus; 1997.

16. Bienfait M. Estudo e Tratamento do Esqueleto Fibroso Fáscias e Pompages. 2 ed. SP:Summus; 1999.

17. Jull GA, O'Leary PS, Falla DL. Clinical assessment of the deep cervical flexor muscles: the craniocervical flexion test. JMPT. September 2008;(7):525-33.

18. Sidhu J. Managing Chronic Neck Pain: Screening and Exercise Protocols. Dynamic Chiropractic Canada. March 1, 2010, (03), Issue 02.

19. Yoshinari NH, Bonfá ESD. Reumatologia para o clínico. São Paulo: Roca; 2000.

20. Moeti P, Marchetti G. Clinical outcome from mechanical intermittent cervical traction for the treatment of cervical radiculopathy: a case series. J Orthop Sports Phys Ther. 2001;(31):207-13.

21. Norlander S, Gustavsson BA, Lindell J, Nordgren B. Reduced mobility in the cervico-thoracic motion segmenta risk factor for musculoskeletal neck-shoulder pain: a two-year prospective follow-up study. Scand J Rehabil Med. 1997;(29):167-74.

22. Browder DA, Erhard RE, Piva SR. Intermittent cervical traction and thoracic manipulation for management of mild cervical compressive myelopathy attributed to cervical herniated disc: a case series. J Orthop Sports Phys Ther. 2004;(34):701-12.

23. Costello M. Treatment Of A Patient With Cervical Radiculopathy Using Thoracic Spine Thrust Manipulation, Soft Tissue Mobilization, And Exercise. The Journal of Manual \& Manipulative Therapy; 2009:(16):129-35.
24. Iglesias JG, De Las-Peñas CF, Cleland J, Veja MG. Thoracic Spine Manipulation for the Management of Patients With Neck Pain: A Randomized Clinical Trial. Therapy, level 1b. J Orthop Sports Phys Ther 2009;39(1):20-7.

25. Wang WT, Olson SL, Campbell AH, Hanten WP, Gleeson PB. Effectiveness of physical therapy for patients with neck pain: an individualized approach using a clinical decision-making algorithm. Am J Phys Med Rehabil. 2003;82:203-218;219-21.

26. Saal JS, Saal JA, Yurth EF. Nonoperative management of herniated cervical intervertebral disc with radiculopathy. Spine. 1996;(21):1877-83.

27. Pereira AG. Os efeitos clínicos de técnicas de terapia manual na cervicobraquialgia (CBO) - um estudo de caso [Trabalho de conclusão de curso]. Santa Catarina: Universidade do Sul de Santa Catarina, 2005.

28. Przyvara LW, Rezende MJ. Tratamento Da Cervicobraquialgia Através Da Técnica De Mobilização Neural. Faculdade Assis Gurgacz - FAG. PR.2008.31.

29. Falla DL. Patients with neck pain demonstrate reduced electromyographic activity of the deep cervical flexor muscles during performance of the craniocervical flexion test. Spine. October 2004;29(19):2108-14.

30. Johnson V. Alterations in cervical muscle activity in functional and stressful tasks in female office workers with neck pain. Eur J Appl Physiol. June 2008;103(3):23-64

31. Ylinen J, Takala EP, Nykanen M, et al. Active neckmuscle training in the treatment of chronic neck pain in women: a randomized controlled trial. JAMA.2003;289:2509-2516.

32. Petersen SM. Articular and muscular impairments in cervicogenic headache: a case report. J Orthop Sports Phys Ther. 2003;33:21-30.

33. Murphy D. Conservative Management of Cervical Spine Syndromes. McGraw-Hill, New York; 2000:20.

Recebido: $12 / 09 / 2012$

Received: 09/12/2012

Aprovado: 19/06/2015

Approved : 06/19/2015 